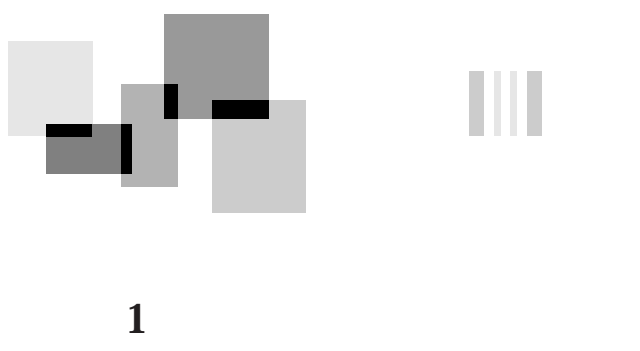

早稲田大学理工学部物理学科 多田隈尚史

1.はじめに

近年, 水溶液中での蛍光色素 1 分子イメージング技術 か我か国で開発された結果, 1 分子生理学が大きく花開 (だ1),2). 1 分子イメージングにより, モータータンパク 質の運動や, 酵素による化学反応の観察, あるいはモー タータンパク質の化学力学変換過程の同時計測がなさ れた. 最近, 1 分子イメージングは生きた細胞にも適用 され, 膜レセプターや接着タンパク質がイメージング されている31,4).これらの実験では, おもにエバネッセ ント場を利用した全反射顕微鏡を用いることで, 照射 範囲を狭め, 背景光を減らして 1 分子イメージングを実 現してきた. しかし,生きた細胞に適用する場合, 全反射 を用いるこの方法ではイメージングが膜表面付近にだ け制限されてしまう. 乥こで我々は細胞内における任 意の高さの 3 次元 1 分子イメージングをめざして, 共焦 点顕微鏡を用いた蛍光色素の 1 分子イメージング法を 開発したので5), 本稿て紹介する.

\section{2. リアルタイム共焦点顕微鏡}

今回我々は市販のビデオレート型共焦点ユニット (横河電機CSU-10) を用いてイメージングを行った (図1). 通常の共焦点顕微鏡は 1 個のピンホールで画面 全体をスキャンするので, 1 枚の画像を得るのに時間が かかり, また観察領域も小さい. 一方, CSU-10は, ニッ ポウディスクと呼ばれるピンホールが多数 ( 2万個) あいているディスクが每分 1800 回転することにより， 顕微鏡の視野 (本研究では $45 \times 30 \mu \mathrm{m}$ ) をリアルタイ 厶 (最速で1秒間に〜 500枚の画像) で観察すること が可能となっている ${ }^{6}$. また, 通常のニッポウディスク 型共焦点ユニットは1枚のニッポウディスクで構成さ
れており, 入射光の数\%しか透過しないのに対して, CSU-10は2枚のニッポウディスクをもっており, 透過 率が50％程度に達している. 兴の結果, ピンホールの部 分で生じる反射光などによるノイズが大幅に削減され， 画質の改善力実現されている. 我々は蛍光色素 1 分子イ メージングを実現するためにさらに“ ひとくふう”を こらした. まず, 標準では共焦点ユニットに光ファイバ (N.A.0.11) で入射光を導入しているが, 代わりにレー ザー光 (YAG2 倍波 : $532 \mathrm{~nm}$ (〜 50 mW) またはHe$\mathrm{Ne}: 633 \mathrm{~nm}(\sim 20 \mathrm{~mW}))$ をN.A.0.01で直接共焦点工 ニットに導入した. このことで, 1 分子イメージングに 必要な励起光強度を稼ぐとともに, 途中の光学部品に 散乱されて迷光となる入射光の割合を少なくし,ノイ ズを低減した. 次に光学フィルターを標準のものから, より1分子イメージングに適したものへと変更した (詳細は文献 5 参照).

イメージングデバイスには超高感度カメラを用いた. 我々はイメージ・インテンシファイアー (VS4-1845, Video Scope) の後乃にICCD (ICCD-350F, Video Scope）をつなげてイメージングしたが, もちろん ICCDの代わりにSIT (浜松フォトニクス) やEB-CCD



図1 リアルタイム共焦点顕微鏡システム ニッポウディスク型共焦点ユニット (横河電気CSU-10) と超高感度カメラを組み合わせてある. 詳細は本文参照.

\title{
Single Molecule Imaging by Real-Time Confocal Microscopy
}

Hisashi TADAKUMA

Department of Physics, School of Science \& Engineering, Waseda University 

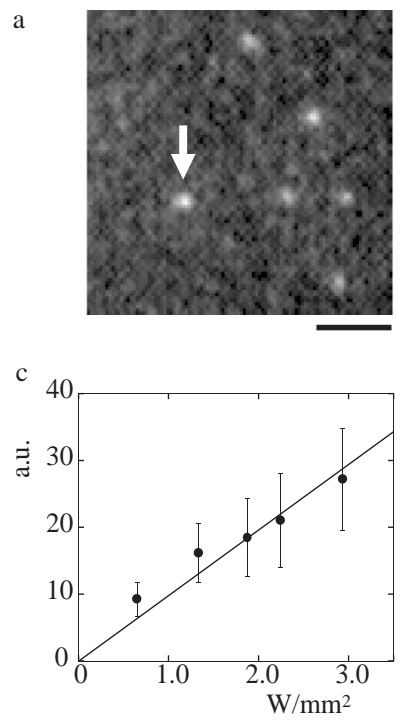

b

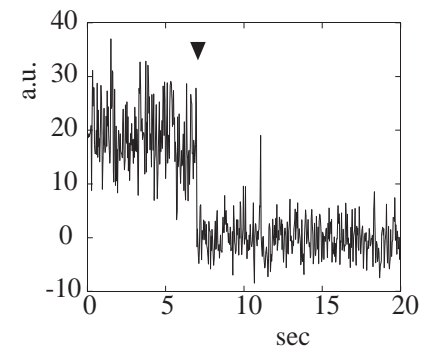

d

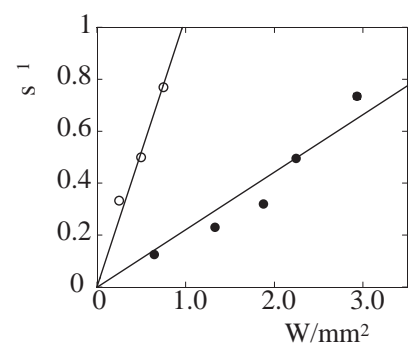

図2 カバーガラス上の蛍光 1 分子イメージング

(a) TMR-キネシンの蛍光像 (8frame 平均像). スケールは $2 \mu \mathrm{m}$. (b) (a) の矢印の蛍光分子の量子的退色 (33ミリ秒ごとの生デ 一タ). (c) 励起光強度を変えた時の1段階で退色したTMR-キネシン分子の蛍光強度. (d) 励起光強度による退色速度 TMR, $\bigcirc$ : IC5).

(浜松フォトニクス) を用いても問題はない. 我々はさ らにイメージ・プロセッサ (Argus20, 浜松フォトニク ス) でコントラストを増強したのちに最終的にS-VHS で録画をした。

\section{2 次元における1分子蛍光イメージング}

この顕微鏡を評価するために, ガラス表面上の蛍光色 素標識したキネシン分子を観察した. ニッポウディス ク型共焦点顕微鏡は多数のピンホールによる照明方法 であるため, 干渉による励起むら (不均一な励起) か洵 になるところであるが, カバーガラス一面にテトラメ チルローダミン (TMR) ラベルしたキネシン分子 (分 子当たりのラベル率 0.6$)$ を結合させて観察したとこ ろ,むらは 10 \%以下であると見積もられた. 次に, TMRキネシンの濃度を薄くしていったところ, だんだんと 観察される分子の数が減っていき, 個々の輝点を観察 できるようになった (図 $2 \mathrm{a}$ : 励起光強度 $1.9 \mathrm{~W} / \mathrm{mm}^{2}$ ).

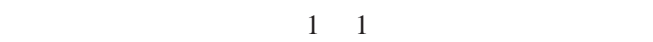
以下のことから示唆された. まず, これらの輝点の蛍光 強度の時間変化を観察すると, 1 蛍光分子に特徵的な性 質である階段退色か観察された (図2b). 次に観察した 輝点のうち, 1段階で退色したものと2段階で退色した ものの分布を取ると, 2 段階で退色した輝点の明るさの 平均は 1 段階のものの約 2 倍であった. これらの結果は, 我々の共焦点顕微鏡で1蛍光色素のイメージングがで きていることを示唆している.
続いて,より詳細な評価を行った.よく知られている 共焦点顕微鏡の問題として, 色素の蛍光強度の飽和が ある (励起光を強くしても蛍光強度が上がらない). 光 こで, 励起光強度を変えた時 $\left(0.65 \sim 3 \mathrm{~W} / \mathrm{mm}^{2}\right)$ の色 素 (TMR) の蛍光強度を測定した (図2c). すると, 事 前の予想と違って, 蛍光強度は励起光にほぼ比例して 強くなった. 我々の観察条件では, 観察画面を256個の ピンホールで同時にスキャンしており, 励起光強度 1.9 $\mathrm{W} / \mathrm{mm}^{2}$ の時には, ピンホールあたりの励起光強度は 12 $\mu \mathrm{W}$ である. 1 本のビームで画面をスキャンするやり方 では励起光がピンホールあたり約 $1 \mathrm{~mW}$ の時に飽和が 起こり始めると報告されており, 我々の観察条件では 飽和強度の $1 / 100$ て観察をしていることになる。

また, 退色速度を各励起光強度で計測したところ, 励 起光強度にほぼ比例した (図 2d). 兴の結果, 励起光強 度 $0.5 \mathrm{~W} / \mathrm{mm}^{2}$ の時ではTMRが〜 10秒, IC5 (Cy5 とほ ぼ同じ波長特性の色素) が〜2秒程度観察できること がわかった. また, 上記のビデオレート共焦点顕微鏡に $475 \mathrm{~nm}$ のレーザーを入射してGFP (S65T) を観察した ところ, 励起光強度 $1.2 \mathrm{~W} / \mathrm{mm}^{2}$ で〜 1 秒程度観察できた.

\section{3 次元の1分子蛍光イメージング}

まず, 3 次元に固定した分子の観察を行った. キネシ ン分子をポリアクリルアミドゲルの中に固定して観察 したところ, 分子がカバーガラス面から離れるほど, 暗 く見える傾向があることがわかった (図3a). 大杂倠把に 


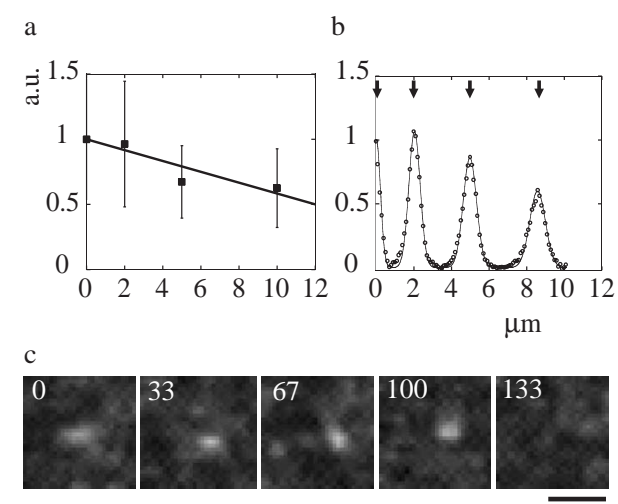

図3 3 次元の 1 分子蛍光イメージング

(a) ポリアクリルアミドゲルに埋まったTMR-キネシン分 子の相対蛍光強度 (カバーガラス面上のTMR-キネシン分 子の蛍光強度を 1 とした. 測定数は $N=76 \sim 116)$. (b) 0.1 $\mu \mathrm{m}$ の蛍光ビーズをゲルに埋めて $0.1 \mu \mathrm{m}$ ごとに蛍光観察し た時の相対蛍光強度 (10 個のビーズの平均值). (c) TMRキネシンの拡散運動 $\left(60 \%\right.$ \%ョ糖溶液中, $\left.23^{\circ} \mathrm{C}\right)$ の連続し た frameの蛍光像 (33ミリ秒ごと). スケールは $2 \mu \mathrm{m}$.

言えばガラス面から $10 \mu \mathrm{m}$ 離れると, 焦点の合っている 分子の明るさは, カバーガラス面上の分子に比べて約 半分になっている.より詳細に観察するために, キネシ ン分子の代わりに $0.1 \mu \mathrm{m}$ の蛍光ビーズをポリアクリル アミドゲルの中に固定して焦点面を $0.1 \mu \mathrm{m}$ ごとに变え ながら, 観察を行った (図3b). するとカバーガラス面 から遠ざかるにつれて, 焦点が合った時の蛍光強度が 下がるとともに, 半值距離 (蛍光強度か焦点面の半分の 強度になるまでの距離) が広がることがわかった.たと えば, カバーガラス上では半値距離は $0.53 \pm 0.1 \mu \mathrm{m}$ (平均 \pm S. D.) であるが, $10 \mu \mathrm{m}$ 上では $1.05 \pm 0.1 \mu \mathrm{m}$ と なった. これは今回の実験では油浸のレンズを用いて いるため, 水と油の屈折率の違いが影響しているもの と考えられる. 害際, 水侵の対物レンズを使えばカバー ガラス面からの距離による影響は減少する (データは 示さず).

次に3 次元を拡散運動しているキネシン分子を観察 した. 観察はビデオレートの時間分解能において測定 するため, 粘性の高い溶液中 $(60 \%$ \% ヨ糖溶液中. 水の 53.2 倍の粘性) で行った. すると, 溶液中を拡散運動す る分子の $x-y$ 方向の軌跡を追跡することができた (図 $3 b)$. 光こで, $x-y$ 方向の軌跡から 2 次元の平均 2 乗変位 を求めてプロットしたところ, 時間間隔に対して線形 に増加していった. この傾きとアインシュタインの式 から, 拡散定数を求めると, $0.75 \mu \mathrm{m}^{2} / \mathrm{s}$ であった. また, 今回の観察では共焦点観察断面 $(\sim 1 \mu \mathrm{m}:$ 輝点の蛍光 強度が焦点面の強度の $20 \%$ 範囲を断面の高さとし
た. 図3b参照) を固定しているため, 分子か断面を通過 する時間からも拡散定数を見積もることができた $\left(0.64 \mu \mathrm{m}^{2} / \mathrm{s}\right)$. これらの值を, 水溶液中の自由拡散時に 換算すると $34 \sim 40 \mu \mathrm{m}^{2} / \mathrm{s}$ となり, 多分子の測定結果と ほぼ同樣の值となった.

以上の結果は, 我々の顕微鏡システムで1個の蛍光色 素が3次元でリアルタイム観察できることを示してお り, 細胞内における 1 分子蛍光イメージングの際に広範 な応用か期待される.

5.まとめ

本稿では, ビデオレート型共焦点顕微鏡を用いた蛍光 1 分子観察に関して述べてきた. 初めの部分でも触れた が, 細胞における 1 分子蛍光観察にはいくつかの方法が あり, 弚れ光れ一長一短ある. まず, 膜近傍の分子を観察 するのであれば, 手軽さとコントラストの良さから対 物型エバネッセント照明が, 初めに挙がる選択肢であ ろう. また, 細胞内でも現象を観察するのに比較的試料 濃度か薄くてもよく, 輝点の密度か非常に低い場合, あ るいは細胞内の特定の場所に停止している分子を観察 する場合などは, 落射照明 や) や斜光照明8) といった方法 が有効であろう. 一方, 現象を観察するのにある程度試 料濃度が必要で背景光がやや高い場合や, 任意の高さ で動き回る輝点を観察・追跡したい時は, 共焦点顕微 鏡が最も有効である. 実験の目的に合わせて, 照明法を 選択するのが肝要であろう.

\section{謝 辞}

本研究を指導していただいた船津高志氏に感謝しま す. また, 本研究を遂行するにあたっては横河電機の田 名網さん・市原さんにお世話になりました.この場を 借りて感謝します.

\section{文 献}

1) Harada, Y. et al. (1998) Methods Cell Biol. 55, 117-128.

2) Weiss, S. (1999) Science 283, 1676-1683.

3) Sako, Y., Minoguchi, S. and Yanagida, T. (2000) Nat. Cell Biol. 2, 168-172.

4) Iino, R., Koyama, I. and Kusumi, A. (2001) Biophys. J. 80, 2667-2677.

5) Tadakuma, H., et al. (2001) BBRC. 287, 323-327.

6) Ichihara, A., et al. (1996) Bioimages 4, 57-62.

7) Kues, T. (2001) Proc. Natl. Acad. Sci. USA 98, 1202112026.

8 ) 德永万喜洋, 今本尚子 : 第39 回日本生物物理学会年会 (大阪, 2001 年 10 月 $6 \sim 8$ 日). 
多田隈尚史 (ただくま ひさし)

早稲田大学理工学部物理学科助手

連絡先 : T 169-8555 新宿区大久保3-4-1

E-mail: tadakuma@aoni.waseda.jp 